Adis Puška ${ }^{1}$

College of Computer Science and

Business Communications eMPIRICA

Adisa Ejubović ${ }^{2}$

Danube University Krems, Krems an der Donau

\section{Admir I. Beganović ${ }^{3}$}

University of Business Studies in Banja Luka
ORIGINAL SCIENTIFIC ARTICLE doi:10.5937/ekonomika1604039P Received: November 22, 2016 Accepted: December 06, 2016

\title{
STUDENT FEEDBACK AS A GUIDELINE FOR HIGHER EDUCATION QUALITY ENHANCEMENT
}

\begin{abstract}
Increasing competition present in the higher education in $B \& H$ has conditioned the trend that institutions need to "fight" for each student via quality development at higher education institutions. This paper deals with means of enhancing quality at eMPIRICA College through continual investigation of students' satisfaction.

For the purpose of this research, we used a quality questionnaire related to quality, satisfaction and loyalty of students. The research was carried out at the start and end of the academic year. This approach ascertained a gap with respect to quality, satisfaction and loyalty of students of eMPIRICA College.

Using factor analysis the statements were grouped in 3 quality dimensions. The results of multivariate analysis of variance (MANOVA) showed that there is a significant statistical difference between expected and perceived quality, satisfaction and loyalty on the part of the students. Based on that, a gap between expectations and perceptions was ascertained. The use of t-test revealed that some statements have significant statistical difference in the area of expected and perceived quality, satisfaction and loyalty of students.
\end{abstract}

Key words: Higher education, quality assurance, multivariate analysis, gap

JEL classification: I23, C38

\section{ИСПИТИВАЊА МИШЉЕЊЕ СТУДЕНАТА У ЦИЉУ ПОВЕЋАЊА КВАЛИТЕТА ВИСОКОГ ОБРАЗОВАЫА}

\section{Апстракт}

Повећањем конкуренције у високом образоваюу у Босни и Хериеговини усло-

\footnotetext{
${ }^{1}$ adispuska@yahoo.com

2 adisa.90@hotmail.com

${ }^{3}$ admirbeganovic52@gmail.com 
вило је тренд да се високошколске установе е морају “борити” за сваког студента кроз развој квалитете. Овај рад се бави начином повећаға квалитетом на Високој школи еМПИРИЦА кроз континуирано истраживање задовољства студената.

За потребе овога рада кориштен је анкетни упитник који се састојао од тврдюи везаних за квалитет, задовољство и лојалност студената. Истражсивање је проведено на почетку и на крају академске године. На овај начин је утврђен јаз у погледу квалитета, задовољства и лојалности студената на ВШ еМПИРИЦА.

Примјеном факторске анализе груписане су тврдње унутар квалитета у 3 димензије квалитета. Резултати проведене мултиваријаџионе анализе варијансе (МАHOВE) су утврдили да постоји значајна статистичка разлика између очекиваног и перцепираног квалитета, задовољства и лојаности студената и на основу тога је утврђено постојање јази код очекивања и периепичје студената. Примјеном т-теста је утврђено код којих појединих тврдюи постоје значајне статистичке разлике у оквиру очекиваног и перципираног квалитета, задовољства и лојалности студената.

Кључне речи: Високог образовања, осигурање квалитете, мултиваријационе анализе, јаз

\section{Introduction}

Higher education in Bosnia and Herzegovina $(\mathrm{B} \& \mathrm{H})$, as in Europe, is facing numerous challenges. Those include: a need for quality enhancement and harmony between teaching and learning on one hand, and the wider social needs and market demands on the other; adjustment to globalisation and an increasing number of students and higher education institutions in the whole world; an increase and dissemination of higher education services using new technologies such as massive open online courses or blended learning (Nanić, 2014, p, 923).

Specific tendencies in higher education in $\mathrm{B} \& \mathrm{H}$ and beyond have influenced the work of higher education where quality as a means to attracting students has become more important. However, Senthikumar and Arulaj (2011) claim that overall higher education quality lags behind primary and secondary education, and more attention needs to be given to higher education.

Higher education institutions as leaders of society development need to offer users a specific quality in their work. Specificity of education is that within its system knowledge is transferred onto the users, and students are the primary users of the educational system. Students acquire new knowledge and competencies in the higher education which they utilise in all segments of life.

Students are the best instruments to measure the quality of higher education since they are the primary users of the educational system. In order to enhance quality system at a higher education institution, it is essential to investigate the satisfaction of students in that institution. Comparison of satisfaction of students in two time periods can give us an 
insight into what has improved/worsened in the system. The investigation is conducted by determining the gap between the expectations and perceptions of students. Through implementation of Bologna Declaration in B\&H educational system, the quality keeps developing. The higher education institution needs to actively apply the quality system as it is the only way to receive all necessary licenses and accreditations (Puška et al., 2015, p. 16). According to the official records retrieved from the website of Centre for Information and Recognition of Qualifications in Higher Education in $\mathrm{B} \& \mathrm{H}$, currently there are 10 public and 38 private higher education institutions which have a license. Out of these, 18 HEIs have received an institutional accreditation and 12 more are in the process of becoming accredited, which puts the quality culture at a higher level in B\&H.

The topic of the paper is to investigate methods of enhancing quality system at eMPIRICA College through determining the gap in the quality system. Determining in what statement there is a gap helps in providing guidelines for enhancing the overall quality level.

Main aim of this paper is enhancement of quality system via determining the gap between the expectations and perceptions of the students. Supporting aims of this paper are to:

- Group the statements on measuring quality into quality dimensions,

- Determine if there is a statistically relevant discrepancy between expectations and perceptions in quality, and satisfaction and loyalty of the students,

- Investigate in which quality statements there is a gap between expectations and perceptions.

- Provide guidelines using the results of the research to enhance quality at eMPIRICA College.

\section{Conceptual framework of the research}

\section{Higher education quality}

Quality in HEIs is equivocal and encompasses teaching delivery (a high-quality curriculum adjusted to the market), high-quality work conditions (well-equipped schools), competent teaching staff (qualified to offer knowledge to students), competent HEI employees (Students' office clerks, expert associates, etc.), etc. (Puška et al., 2015a, p. 16).

Due to its complexity and multidimensionality, the quality needs to be observed from various angles, out of which students' opinion is the most important as they are direct participants in the higher education system. So as to maintain the quality level, all actors and work conditions at a higher education institution have to be oriented toward quality enhancement.

Quality system is not merely introduced so as to meet legal regulations, but the quality needs to serve in building satisfaction of the student, who will be loyal. (Puška et al., 2015b, p. 104)

The system of quality assurance guarantees that the subject of higher education pays attention to the purpose of its existence, to the processes that contribute to the creation of experts and to people who plan and conduct education processes and scientific an research work (Mencer, 2005, p. 241). 
Main tendencies in the field of assuring and enhancing quality of higher education are conveyed through (Lazić, 2007, p. 1):

- Ascertaining unique criteria of assuring and guaranteeing the quality of education within the frame of Bologna process,

- Developing, determining and balancing national systems of accrediting HEIs and study programs and

- Elaborating on and introducing the quality management system based on different QMS models.

Establishment of quality system in European countries is conditioned by Bologna Declaration on development of higher education. "A wide spectrum of evaluation and accreditation programs of individual countries in the EU and the rest of the world considerably hinders the establishment of unique quality standards in higher education, comparison of accredited programs, curricula or institutions, as well as mobility of students and staff" (Petković, Jašarević, 2005, p. 288). It is precisely curricula, teaching staff and students that are key parameters of development and enhancement of quality in higher education.

Guolla (1999) deems that positive perceptions of quality can lead to students' satisfaction and an increase in the number of students at the institution. Each HEI strives to achieve a competitive advantage and attract new students and keep the existing ones by enhancing the quality system (Temizer, Turkyilmaz, 2012, p. 3802).

\section{Instruments for measuring quality in higher education}

Different research applied different instruments to measure quality in higher education. Many researchers have readjusted SERVQUAL model for measuring quality for the purpose of investigating students' satisfaction with the quality. Original SERVQUAL, created by Parasuraman et al., (1988) had its 10 dimensions reduced to 5, those being: tangibles, reliability, responsiveness, assurance and empathy.

By readjusting SERVQUAL model Owlia and Aspinwall (1996) suggested six dimensions to measure quality in higher education, those being: tangibles (appropriate equipment and facilities), competence (vocational classes, practical and theoretical knowledge), attitude (understanding needs of students, friendliness, personal care, etc.), content (practical application of curriculum, knowledge flexibility, etc.), delivery (effective presentations, feedback from students, etc.), reliability (trust, solving complaints and problems etc.). As it was mentioned above, HEI services are specific as they are used to transfer knowledge to students and for that reason it is not possible to apply the classical instrument for measuring service quality. Furthermore, Ho and Wearn (1996) incorporated SERVQUAL into HETQMEX model which is excellence model for higher education, while Klarić and Kulašin (2011) have developed SERVQUAL into HEDUQUAL model for measuring higher education quality.

In addition to SERQUAL model for measuring higher education quality, the following models are also used:

- $\quad$ SERVPERF measures service quality based on the perceived service factors. It is in essence SERVQUAL model that differs in that it measures students' perceptions, not expectations. 
- HEdPERF was developed by Firdaus (2006) and it serves as a measuring instrument of service quality exclusively for higher education which consists of the following dimensions: non-academic aspects, academic aspects, reputation, approach and understanding. It is precisely SERVPREF and HEdPREF that represent the best instruments for measuring higher education quality, but it is not possible to determine which one is better (Camgoz-Akdag, Zaim, 2012, p. 875).

- EduQUAL is specifically suggested for education sector. It is used for measuring satisfaction level of different participants (Mahapatra, Khan, 2007, p. 289). This measuring instrument consists of the following dimensions: learning outcomes, responsibility, physical facilities, personality development and academic aspects.

- EDUSERVE was developed based on SERVQUAL measuring instrument which served for measuring the expectations and perceptions of quality in Mauritius high schools (Ramseook-Munhurrun et al., 2010). It consists of the following dimensions: empathy, school facilities, reliability, responsiveness and assurance of students' discipline.

\section{Satisfaction and loyalty of students}

Satisfaction is defined as a rate of the total service and service experience in the preceding period (Lin et al., 2010). Loyalty is a term connected to dedication of clients to a specific brand, shop or supplier based on the positive attitude and is reflected in the repeated purchase (Ningsih, Segoro, 2014, p. 1017). When applied to higher education system satisfaction is experience with higher education service while loyalty is students' dedication to higher education institution they attend, as well as their desire to continue their education there. The most important indicator in HEI quality research is precisely loyalty and satisfaction of students. A loyal and satisfied student helps in development of that higher education institution. Keeping the levels of loyalty and satisfaction of students is impossible without the implementation of quality system at that HEI (Puška et al., 2015a, p. 17). Connection of these two concepts with quality was dealt with in numerous studies. Puška et al., (2015a and 2015b) in their two studies connected quality perception with satisfaction and loyalty of students using multiple regression and canonical-correlation analysis and proved that a satisfied student is a loyal student. Negricea et al., (2014) investigated the connection of quality perception with satisfaction of students. Dib and Alnazer (2013) investigated how quality system is connected to satisfaction and loyalty of students. Dado et al., (2012) connected quality system with students' behaviour. Temizer i Turkyilmaz (2012) investigated how quality perception affects students' satisfaction index and its connection to loyalty.

Investigating loyalty and satisfaction is very important for each HEI. "Students transfer their satisfaction with work and quality of a HEI to others, and in that manner s/he represents that institution in the best possible way. On the other hand, a dissatisfied student will not represent the institution in the best way and in that manner the reputation and image of the institution suffers, which can result in a fewer number of enrolled students and migration of students to another institution." (Puška et al., 2015b, p. 103).

If the university meets the expectations, the student will be satisfied and will be the best promoter of the university. The aim of education service flow is the satisfaction of the student, which leads to loyalty and projects itself to the continuation of the studies (masters, doctoral 
studies, etc.) or initiates positive references to potential students and partners (general public) (Gajić, 2011, p. 73). Due to everything abovementioned for each HEI, it is very important to monitor its quality system, as well as the satisfaction and loyalty of its students.

\section{Hypotheses of research}

Higher education institution influences students through the established quality system. Yahnong Li and Kaye (1999) conducted a research on the sample of 228 students and proved that students' expectations are relatively stable in a period of time, while their perception of service quality changes during their studies and the perceived level of quality decreases as the studies progress. This research showed that all students have high expectations from HEIs, but the perceived quality decreases. For that reason it is necessary to enhance the quality system in HEIs so as the expected and perceived quality levels are approximately the same so that the students are satisfied with the HEI. Based on this and similar research the first hypothesis is formulated as follows:

- There is a significant statistical difference between quality dimensions based on expected and perceived quality level with students.

Satisfaction is the key factor of business success and implementation of quality system (Lin, Tsin, 2008). Due to that fact, it is very important to investigate satisfaction of students and determine if it changes over a period of time and if students' satisfaction increases or decreases during their studies. If students' satisfaction decreases during their studies, they will not be interested in continuing the following cycles at that HEI, and it is debatable if they will complete the current cycle at that HEI. Based on the abovementioned the second hypothesis is formulated as follows:

- There is a significant statistical difference in students' satisfaction at the start and end of the academic year.

Since the quality system is connected to satisfaction, and satisfaction, in turn, to loyalty of students, it is necessary to investigate if and how the loyalty of students changes. The mentioned studies have shown that these three research variables are mutually related. Loyal students continue other cycles at that HEI and recommend it to others (Temizer, Turkyilmaz, 2012). Based on that, it is necessary to investigate if and how the loyalty of students changes so as to enhance the quality at the HEI. For that purpose, the third hypothesis is formulated as follows:

- There is a significant statistical difference in students' loyalty at the start and end of the academic year.

To prove the proposed hypotheses the research will use multivariate analysis of variance (MANOVA). Based on that, the following variables are proposed: independent variable - conducted research in two time periods and dependent variables - quality dimension, satisfaction and loyalty of students.

\section{Research methodology}

For the purpose of this paper, empirical research was conducted at eMPIRICA College on two occasions. The first research and collection of primary data was conducted at the start of academic year 2014/2015, while the second research was conducted at the end of 
the same academic year. The research was conducted on two occasions so as to determine the gap between expected level of quality, satisfaction and loyalty (the research at the start of the academic year) and perceived level of quality, satisfaction and loyalty (the research conducted at the end of the academic year). The point of this research is to monitor and enhance quality at the HEI.

Both pieces of research used the same questionnaire taken from our co-founder Ljubljana School of Business, Slovenia which consisted of 4 parts:

- 15 statements related to quality which encompassed different segments of a higher education institution: teaching and administrative staff, availability of information, facilities and equipment, as well as reaction of the institution to the needs and desires of students. Due to variety of statements, factor analysis will be used to determine quality dimensions,

- 5 statements to measure students' satisfaction,

- 5 statements to measure students' loyalty,

- Participants' characteristics (gender, year of study, study program, mode of studying).

First three groups of the questionnaire used five-level Likert scale, where students were required to provide their level of concurrence with the proposed statements ( 1 - strongly disagree, 5 - strongly agree). The fourth group of questions is related to the characteristics of the students: their gender, year of study, program study and mode of study. In both cases a web-based questionnaire was used which was uploaded to the scientific portal - $1 \mathrm{ka}$.si - and the students received the link to the questionnaire. In the first research, the questionnaire was filled out by 85 students, which is 75 percent of the total number as there are 112 students in all three years of study. Due to the low total number, the research used purposive sampling, that is, the link was sent to all students via a personal message through e-learning platform - eCampus.

Overall statistical data analysis was carried out in the software package SPSS 20.0. which used several statistical methods. The reliability of the acquired data was measured using statistical analysis called Cronbach' alpha. Factor analysis investigated reliability of data based on Kaiser-Meyer-Olkin (KMO) test and Bartlett's test.

Apart from the need to investigate the proposed hypotheses, it is necessary to determine what statements within quality dimensions show the gap between the expected and perceived quality level and to what extent, so as to provide guidelines for enhancement of quality at eMPIRICA College. This approach will also determine the gap between satisfaction and loyalty of students so as to enhance loyalty and satisfaction of students at eMPIRICA College. In the course of proving this hypothesis and aims the following methodology will be used:

- Step 1: Grouping statements into quality dimensions using factor analysis,

- Step 2: Investigating reliability of the collected data using Crombach alpha,

- Step 3: Investigating the proposed research hypotheses using MANOVA and

- $\quad$ Step 4: Investigating the gap between the expected and perceived quality using t-test.

\section{Results of the research}

The questionnaire was filled out by 84 students the first time, and second time it was filled out by 85 students and the following table shows the general characteristics of the subjects. 
Table 1: General characteristic of the subjects

\begin{tabular}{llcc}
\hline \multicolumn{1}{c}{ Factor } & \multicolumn{1}{c}{ Category } & $\begin{array}{c}\text { Percentage in the } \\
\text { 1st research }\end{array}$ & $\begin{array}{c}\text { Percentage in the } \\
\text { 2nd research }\end{array}$ \\
\hline \multirow{2}{*}{ Study program } & Engineering Informatics & $46.4 \%$ & $50.6 \%$ \\
& Business Informatics & $53.6 \%$ & $49.4 \%$ \\
\hline \multirow{2}{*}{ Mode of studies } & Full-time studies & $26.2 \%$ & $27.1 \%$ \\
& Distance-learning studies & $73.8 \%$ & $72.9 \%$ \\
\hline \multirow{2}{*}{ Gender } & Male & $89.3 \%$ & $84.7 \%$ \\
& Female & $10.7 \%$ & $15.3 \%$ \\
\hline \multirow{2}{*}{ Year of study } & First & $23.8 \%$ & $28.2 \%$ \\
& Second & $37.0 \%$ & $38.8 \%$ \\
\hline \multirow{2}{*}{ Total number of students } & $39.2 \%$ & $32.9 \%$ \\
\hline \multicolumn{2}{c}{ Source: Research results } & $\mathbf{8 4}$ & $\mathbf{8 5}$ \\
\hline
\end{tabular}

Since the questionnaire was anonymous, it was not possible to compare the answers of the specific students and determine the discrepancy between them. However, since the general answers will be observed in two pieces of research and it will not be dealt with subtle differences in the observed categories of the subjects, these characteristics are considered acceptable for the further investigation.

To examine the reliability of the factor analysis results, we used Kaiser-Meyer-Olkin (KMO) measure of sampling adequacy and Bartlett test of sphericity. KMO indicator ranges from 0 to 1 . If the value of that measure is below 0.6 , the correlation matrix will not be appropriate for the factor analysis. With Bartlett's test it is desirable that the significance value is below $0.05(\mathrm{p}<0.05)$.

In the course of running factor analysis the analysis of main components was used, as well as Varimax factor rotation with Kaiser normalization. In the choice of number of factors we used unit root method, that is, Kaiser criterion.

Table 2 : Results of factor analysis on quality dimensions

\begin{tabular}{|c|c|c|c|}
\hline Factor & Quality-related statements & $\begin{array}{c}\text { Factor } \\
\text { value }\end{array}$ & $\begin{array}{c}\text { Statement } \\
\text { code }\end{array}$ \\
\hline \multirow{8}{*}{1} & Employees provide support to the students & .780 & VAR06 \\
\hline & $\begin{array}{l}\text { Employees help students in solving problems encountered in the } \\
\text { course of the studies }\end{array}$ & .754 & VAR03 \\
\hline & Employees always think in students' best interests & .753 & VAR04 \\
\hline & The College looks after students' wellbeing & .740 & VAR07 \\
\hline & Students' complaints are solved quickly & .738 & VAR02 \\
\hline & The College keeps promises it has made to the students & .731 & VAR05 \\
\hline & $\begin{array}{l}\text { Employees in the College pay attention to the specific needs and } \\
\text { wishes of the students }\end{array}$ & .717 & VAR01 \\
\hline & Administrative staff at the College is pleasant & .530 & VAR08 \\
\hline
\end{tabular}

Explained variance 53.672\%, Cronbach's alpha 0.921 


\begin{tabular}{|c|c|c|c|}
\hline \multirow{5}{*}{2} & Lecturers are available via electronic media & .803 & VAR12 \\
\hline & Lecturers connect theory and practice & .674 & VAR11 \\
\hline & Lecturers treat students in a transparent way & .661 & VAR13 \\
\hline & $\begin{array}{l}\text { Lecturers use modern scientific methods in transferring } \\
\text { knowledge }\end{array}$ & .653 & VAR10 \\
\hline & College employees are always at students' disposal & .624 & VAR09 \\
\hline \multicolumn{4}{|c|}{ Explained variance $7.393 \%$, Cronbach's alpha 0.853} \\
\hline \multirow{2}{*}{3} & The College has solid equipment & .837 & VAR14 \\
\hline & College facilities are comfortable & .792 & VAR15 \\
\hline
\end{tabular}

Explained variance $7.137 \%$, Cronbach's alpha 0.796

KMO = 0.927; Bartlett's test $p<0.000$; Total variants explained $68.202 \%$

Source: Research results

Before the factor analysis results are interpreted, it is necessary to determine values of Bartlett's test and values of KMO test. Measure of sampling adequacy is represented through $\mathrm{KMO}$ test and using Bartlett's test of sphericity it is aimed to determine the meaning of correlations within correlation matrix. Results obtained through factor analysis show that the data are adequate for factor analysis since value of KMO test is 0.9279 , which is almost 1 . Specificity test is of significant importance since it implies that the correlation matrix is not unit, which the test has proven.

Factor analysis results (table 2) have shown that in accordance with 15 statements that were used to measure quality at the higher education institution, 3 dimensions stand out, which are shown as factor 1-3.

Factor 1 - Administrative help provided for students. This first quality dimension describes students' needs and help provided for their wellbeing using 8 statements. The first factor explained $53.67 \%$ of the variance of the main group so the reliability of the collected data is very high. The value of Cronbach's alpha is 0.937 as the values for Cronbach's alpha range from theoretical 0 (zero) to 1 . If the values of this indicator are close to zero then that data is said to be unreliable. If those values are close to one it can be said that the data is reliable.

Factor 2 - Satisfaction with the administrative and teaching staff. This second quality dimension is described using 6 statements which are related to student's satisfaction with administrative staff and information they received from the College. The second dimension explained $7.39 \%$ of the variance and it also has a high reliability of the collected data. Cronbach's alpha value is 0.890 .

Factor 3 - Facilities. The third quality dimension consists of merely 2 statements related to satisfaction with College equipment and facilities as well as College's keeping promises. This factor explains $7.137 \%$ of the main group variance and the value of Conbach's alpha is 0.766 . It does not represent a high reliability, but it can be taken into consideration. It is necessary to point out that that "if all values of this indicator are below and equal to 0.75 one should reconsider if that data should be taken into account" (Leontitsis, Pagge, 2007: 336). Since the value of Cronbach's alpha is over 0.75 the data will be taken into consideration.

After the quality dimensions have been determined factor analysis of the remaining two variables was done, those being satisfaction and loyalty. 
Results of the factor analysis (table 3 ) have shown that all the conditions for conducting this analysis have been fulfilled, which is corroborated by KMO and Bartlett's test results. All five statements used to investigate satisfaction have been grouped in one factor and it explained $74.9 \%$ of the main group variance. There is a high reliability present in these data as the value of Cronbach's alpha is 0.915 . Based on factor analysis and Cronbach's analysis, it has been shown that the statements used for satisfaction of students are related and reliable.

Upon conducting factor analysis on satisfaction of students, factor analysis for statements on loyalty of students will be conducted as well. Results of KMO and Bartlett's test show that the used matrix is not a unit matrix and that there is a relation between the used statements which fulfilled the propositions for the use of factor analysis.

Conducted factor analysis has shown that there is only one factor related to students' loyalty and that factor explains $75.3 \%$ of the main group variance. Cronbach's alpha test shows that the data are reliable since its value is 0.919 .

Table 3 : Results of factor analysis on satisfaction and loyalty variables

\begin{tabular}{|c|c|c|c|}
\hline Factor & Student satisfaction statements & $\begin{array}{l}\text { Factor } \\
\text { value }\end{array}$ & $\begin{array}{c}\text { Statement } \\
\text { code }\end{array}$ \\
\hline & $\begin{array}{l}\text { I think I have done the right thing by selecting } \\
\text { education at this College }\end{array}$ & .901 & VAR16 \\
\hline & I do not regret enrolling in this College & .893 & VAR17 \\
\hline & I am satisfied with my College choice & .868 & VAR18 \\
\hline & My experience of this College is very pleasant & .853 & VAR19 \\
\hline & Generally speaking, I am satisfied with this College & .806 & VAR20 \\
\hline \multicolumn{4}{|c|}{ Explained variance $74,825 \%$, Cronbach's alpha 0,915} \\
\hline \multicolumn{4}{|c|}{$\mathrm{KMO}=0,837 ;$ Bartlett's test $\mathrm{p}<0.000$} \\
\hline \multirow[t]{6}{*}{ Factor } & Student loyalty statements & $\begin{array}{c}\text { Factor } \\
\text { value }\end{array}$ & $\begin{array}{c}\text { Statement } \\
\text { code }\end{array}$ \\
\hline & I would recommend the College I attend to others & .909 & VAR21 \\
\hline & $\begin{array}{l}\text { If I had to choose again I would choose the same } \\
\text { school }\end{array}$ & .890 & VAR22 \\
\hline & I am proud to be a student of this College & .855 & VAR23 \\
\hline & I only say good things about this College & .854 & VAR24 \\
\hline & $\begin{array}{l}\text { If given an opportunity to continue my education, I } \\
\text { would do it at this College }\end{array}$ & .841 & VAR25 \\
\hline \multicolumn{4}{|c|}{ Explained variance $75,732 \%$, Cronbach's alpha 0,919} \\
\hline \multicolumn{4}{|c|}{ KMO = 0,876; Bartlett's test $p<0.000$} \\
\hline
\end{tabular}

Source: Research results

Upon investigating the reliability of the used data we move on to test the proposed research hypotheses. Testing hypotheses will be carried out using MANOVA analysis and using Wilks' Lambda indicator. MANOVA is the extension of variance analysis which is used when there are more than one (two or more) dependent variables. "MANOVA compares groups and shows if it is probable that the mean differences in group influences on that combination of dependent variables are correct and if it shows the possibilities those groups manifest". (Memet, 2011, p, 76). 
Examination of the hypotheses will be carried out with $95 \%$ reliability of accepting the correct hypothesis, that is, p-value should be below 0.05 . In the course of conducting this analysis, the most important things are the indicator of significance and F-test value. For the level of significance, the lower p-value, the better, while the higher F-test value, the better, since it is precisely that which proves that there is greater statistical difference between two or more observed groups. With MANOVA analysis the results from two pieces of research are taken as an independent variable - one for the start of the academic year and the other one for the end of the academic year. As a dependent variable with the first hypothesis we took quality dimensions, with the second hypothesis we took students' satisfaction variable and with the third hypothesis we took students' loyalty variable.

Table 4 : MANOVA analysis results using Wilks'Lambda indicator

\begin{tabular}{lcccc}
\hline Dependent variables & Value & F & Sig. & Hypothesis status \\
\hline Quality dimensions & .794 & 2.650 & 0.001 & Accepted \\
Students' satisfaction & .929 & 2.497 & 0.033 & Accepted \\
Students' loyalty & .846 & 5.952 & 0.000 & Accepted \\
\hline
\end{tabular}

Source: Research results

MANOVA results show (table 4) that in proving the third hypothesis there is the greatest statistical difference in students' answers. F-test result is the greatest and it is 5.952 . The lowest one is the significance level. P-value is 0.000 , which makes the third hypothesis acceptable, with $0.0 \%$ risk level that the true hypothesis will be rejected. Furthermore, this analysis has the lowest value of Wilks' Lambda indicator and it is $\lambda=0.846$.

Furthermore, MANOVA results show that the first hypothesis is accepted, that is, that there is a significant statistical difference between quality dimensions based on expected and perceived quality level by the students. With proving this hypothesis, the value of F-test is 2.650, while the level of significance is 0.001 , which makes this hypothesis acceptable with 0.1 risk level that the true hypothesis will be rejected. The value of Wilks' Lambda indicator with this analysis is $\lambda=0.794$.

The second hypothesis proposed can be accepted since there is a significant statistical difference between students' satisfaction at the start and end of the academic year, which is also supported by the level of significance. P-value is 0.033 , while the value of F-test in this analysis is 2.497 . In this analysis the value of Wilks' Lambda indicator is $\lambda=0.929$. However, examination of the second hypothesis shows that there is $3.3 \%$ probability that the true hypothesis is rejected.

By examining the given results of t-test (table 5) we can see that only one statement has a positive value of this test because expectations for that statement were lower than the perception at the end of the academic year. That statement is "Administrative staff at the College is very pleasant" and its value is 0.06681 . Examining other values we can observe that with the statement that the "College has solid equipment" there is the largest gap between students' expectations and perceptions and it is -0.62591 . Observing the significance level (sig) it can be seen that in all but three statements this level is lower than $5 \%$, that is, the p-value is $<0.05$. Those statements are: "Employees always think in students' best interest", "Administrative staff at the College is pleasant" and "College employees are always at 
students' disposal". It can be said that for these three statements there is the smallest deviation from students' perceptions and expectations.

Based on t-test results, it can be concluded that eMPIRICA College needs to work more on quality enhancement so as to decrease the gap between students' expectations and perceptions on providing information to students and improve equipment and facility quality. Based on this test, it is evident that all but one statement show a negative difference, that is, students' expectations were higher than the perceptions at the end of the academic year. This College's Management should analyse in more detail these results and make decisions so as to enhance the quality system at this institution and thus reduce the gap between expectations and perceptions of that quality.

Table 5 : Difference between expectations and perceptions of students regarding quality

\begin{tabular}{ccccccc}
\hline $\begin{array}{c}\text { Statement } \\
\text { Code }\end{array}$ & $\begin{array}{c}\text { Perception } \\
\text { mean }\end{array}$ & $\begin{array}{c}\text { Expectation } \\
\text { mean }\end{array}$ & t-test & $\begin{array}{c}\text { Freedom } \\
\text { degree }\end{array}$ & Sig. & $\begin{array}{c}\text { Mean } \\
\text { difference }\end{array}$ \\
\hline Quality dimension - Administrative help provided for students & \\
\hline VAR01 & 3.8824 & 4.2381 & -2.848 & 167 & .005 & -.35574 \\
VAR02 & 3.7176 & 4.2024 & -3.316 & 167 & .001 & -.48473 \\
VAR03 & 4.1412 & 4.3929 & -2.200 & 167 & .029 & -.25168 \\
VAR04 & 3.9647 & 4.1667 & -1.473 & 167 & .143 & -.20196 \\
VAR05 & 3.7059 & 4.1190 & -2.908 & 167 & .004 & -.41317 \\
VAR06 & 4.2000 & 4.4286 & -2.118 & 167 & .036 & -.22857 \\
VAR07 & 3.8588 & 4.2857 & -3.397 & 167 & .001 & -.42689 \\
VAR08 & 4.3882 & 4.3214 & .590 & 167 & .556 & .06681 \\
\hline \multicolumn{7}{c}{ Quality dimensions - Satisfaction with the administrative and teaching staff } \\
\hline VAR09 & 4.2235 & 4.4524 & -1.853 & 167 & .066 & -.22885 \\
VAR10 & 4.0941 & 4.4762 & -3.307 & 167 & .001 & -.38207 \\
VAR11 & 4.1412 & 4.3810 & -2.122 & 167 & .035 & -.23978 \\
VAR12 & 4.2588 & 4.5833 & -2.862 & 167 & .005 & -.32451 \\
VAR13 & 4.3294 & 4.5595 & -2.196 & 167 & .029 & -.23011 \\
\hline \multicolumn{7}{c}{ Quality dimension - Facilities } \\
\hline VAR14 & 3.5765 & 4.2024 & -4.029 & 167 & .000 & -.62591 \\
VAR15 & 3.8235 & 4.3452 & -3.795 & 167 & .000 & -.52171 \\
\hline \multicolumn{7}{c}{ Student satisfaction } \\
\hline VAR16 & 4.1765 & 4.4524 & -2.427 & 167 & .016 & -.27591 \\
VAR17 & 4.1882 & 4.4643 & -2.192 & 167 & .030 & -.27605 \\
VAR18 & 4.1882 & 4.5357 & -3.012 & 167 & .003 & -.34748 \\
VAR19 & 4.0353 & 4.4048 & -3.117 & 167 & .002 & -.36947 \\
VAR20 & 4.0706 & 4.4167 & -2.797 & 167 & .006 & -.34608 \\
\hline VAR21 & 4.0000 & 4.5476 & -4.185 & 167 & .000 & -.54762 \\
VAR22 & 3.9176 & 4.2381 & -2.186 & 167 & .030 & -.32045 \\
VAR23 & 3.9647 & 4.3214 & -2.841 & 167 & .005 & -.35672 \\
VAR24 & 4.0941 & 4.4881 & -2.969 & 167 & .003 & -.39398 \\
\hline & 3.8941 & 4.4524 & -4.068 & 167 & .000 & -.55826 \\
\hline
\end{tabular}

Source: Research results 


\section{Conclusion}

The research in this paper has been conducted on two occasions: at the start and end of the academic year with the aim of examining the gap between expectations and perceptions of the students. The results have shown that there is a negative difference in all research variables, that is, the expectations exceed the perceptions of students and average deviation is from 4 to 12 percent. Only with the statement "Administrative staff at College is very pleasant" there is a positive difference, that is, a positive gap. Based on the calculated gap and results of ANOVA and t-test, the conclusions can be made as to what statements need more work so as to enhance the quality system at higher education institutions.

In the course of examining quality at eMPIRICA College, we used 15 statements which were grouped into 3 quality dimensions using factor analysis. Since the questionnaire was taken from eMPIRICA College co-founders, it had some disadvantages as it did not include some other statements and dimensions used in e.g. SERVPREF and HEdPREF models for measuring quality. This research has shown that it is necessary to separate teaching staff from administrative and technical staff in the course of measuring quality of the staff and treat them as separate quality dimensions as higher education institutions primarily transfer knowledge onto students via teaching staff and by using equipment and facilities. It is also necessary to include more statements on equipment and facility quality and reduce statements related to the needs and help to students.

The recommendations for the future research are that in the course of creating a new model for measuring quality at higher education institutions it is necessary to include more different statements and determine which dimensions are of primary significance for the quality. Furthermore, it is necessary to apply this questionnaire to different HEIs so as to gain more complete information from students rather than merely conduct this type of research on only one HEI. Only in that way can we get a valid model for measuring quality at higher education institutions.

\section{References}

Camgoz-Akdag, H., \& Zaim, S. (2012). Education: a comparative structural equation modeling study. Procedia - Social and Behavioral Sciences, 47, 874-880.

Dado, J., Taborecka Petrovicovaa, J., Cuzovicband, S., \& Rajic, T. (2012). An Empirical Examination of the Relationships Between Service Quality, Satisfaction and Behavioral Intentions in Higher Education Setting. Serbian Journal of Management, $7(2), 203-218$

Dib, H., \& Alnazer, M. (2013). The Impact of Service Quality on Student Satisfaction and Behavioral Consequences in Higher Education Services. International Journal of Economy, Management and Social Sciences, 2(6), 285-290.

Firdaus, A. (2006). The development of HEdPERF: a new measuring instrument of service quality for the higher education sector. International Journal of Consumer Studies, 30(6), 569-581.

Gajić, J. (2011). Merenje satisfakcije studenata u visokom obrazovanju. Marketing, 42(1), $71-80$. 
Grandić R., \& Stipić M. (2011). Novi kvalitet obrazovanja: šansa za bolju budućnost. Pedagoška stvarnost, 56(5-6), 410-425.

Guolla, M. (1999). Assessing the teaching quality to student satisfaction relationship: applied customer satisfaction research in the classroom. Journal of Marketing Theory and Practice, 7(3), 87-97.

Ho, S. K., \& Wearn, K. (1996). A higher education TQM excellence model: HETQMEX. Quality Assurance in Education, 4(2), 35-42.

Klarić, S., \& Kulašin, Dž. (2011). Konstrukcija heduqual instrumenta za mjerenje glavnih faktora usluge visokog obrazovanja u B\&H. 7. Naučno-stručni skup sa međunarodnim učešćem "KVALITET 2011", 821-828.

Lazić, M. (2007). Sistem kvaliteta-QMS u visokom obrazovanju. Nacionalna konferencija o kvalitetu (XXXIV). Selekcija A-1., 1-6.

Leontitsis, A., \& Pagge, J. (2007). A simulation approach on Cronbach's alpha statistical significance. Mathematics and Computers in Simulation, 73(5), 336-340.

Lin, C. P., \& Tsai, Y. H. (2008). Modeling educational quality and student loyalty: a quantitative approach based on the theory of information cascades. Quality and Quantity, 42(3), 397-415.

Lin, R. J., Chen, R-H., \& Chiu, K. K-S. (2010). Customer relationship management and innovation capability: An empirical study. Industrial Management \& Data Systems, 101(1), 111-133.

Mahapatra, S. S., \& Khan, M. S. (2007). A neural network approach for assessing quality in technical education: an empirical study. International Journal of Productivity and Quality Management Decision, 2(3), 287-306.

Memet, A. (2011). Analiza preduzeća u Srbiji u uslovima svetske ekonomske krize. Singidunum Revija, 8(2), 72-78.

Mencer, I. (2005). Osiguranje kvalitete i visokoškolske ustanove u Republici Hrvatskoj. Ekonomski pregled, 56(3-4), 239-258.

Nanić, H. (2014). Visoko obrazovanje: Izazovi i perspektive u moderno doba. In: Zbornik radova II međunarodna konferencija Bosna i Hercegovina i Euroatlantske integracije, Trenutni izazovi i perspektive, 919-928.

Negricea, C. I., Edu, T., \& Avram, E. M. (2014). Establishing Influence of Specific Academic Quality on Student Satisfaction. Procedia - Social and Behavioral Sciences, 116, 4430-4435.

Ningsih, S. M., \& Segoro, W. (2014). The influence of customer satisfaction, switching cost and trusts in a brand on customer loyalty - the survey on student as im3 users in Depok, Indonesia. Procedia - Social and Behavioral Sciences, 143, 1015-1019.

Owlia, M., \& Aspinwall, E. (1996). A Framework for the Dimensions of Quality in Higher Education. Quality Assurance in Education, 4(2), 12-20.

Parasuraman, A., Zeithaml, V. A., \& Berry, L. L. (1988). SERVQUAL: A multiple-item scale for measuring customer perceptions of service quality. Journal of Retailing, 6(41), 12-40. 
Petković, D., \& Jašarević S. (2005). Razvoj sistema upravljanja kvalitetom na Univerzitetu u Zenici kroz prizmu bolonjskog procesa. 4. Naučno-stručni skup sa međunarodnim učešćem "KVALITET 2005", 287-294.

Puška, A., Stanišić, D., Maksimović, A. (2015a). Utjecaj sustava kvaliteta na zadovoljstvo i odanost studenata VŠ eMPIRICA. Praktični menadžment, 6(1), 15-21.

Puška, A., Maksimović, A., \& Fazlić, S. (2015b). Uticaj kvaliteta na zadovoljstvo i lojalnosti studenata. Poslovna izvrsnost, 9(2), 101-119.

Ramseook-Munhurrun, P., Naidoo, P., \& Nundlall, P. (2010). A proposed model for measuring service quality in secondary education. International Journal of Quality and Service Sciences, 2(3), 335-351.

Senthilkumar, N., \& Arulraj, A. (2011). SQM-HEI- determination of service quality measurement of higher education in India. Journal of Modelling in Management, 6(1), 60-78.

Temizer, L., \& Turkyilmaz, A. (2012). Implementation of student satisfaction index model in higher education institutions. Procedia - Social and Behavioral Sciences, 46, 3802-3806.

Yanhong Li, R., \& Kaye, M. (1999). Measuring Service Quality in the Context of Teaching: A study on the longitudinal nature of Students' Expectations and Perceptions. Innovations in Education and Training International, 36(2), 145-154. 